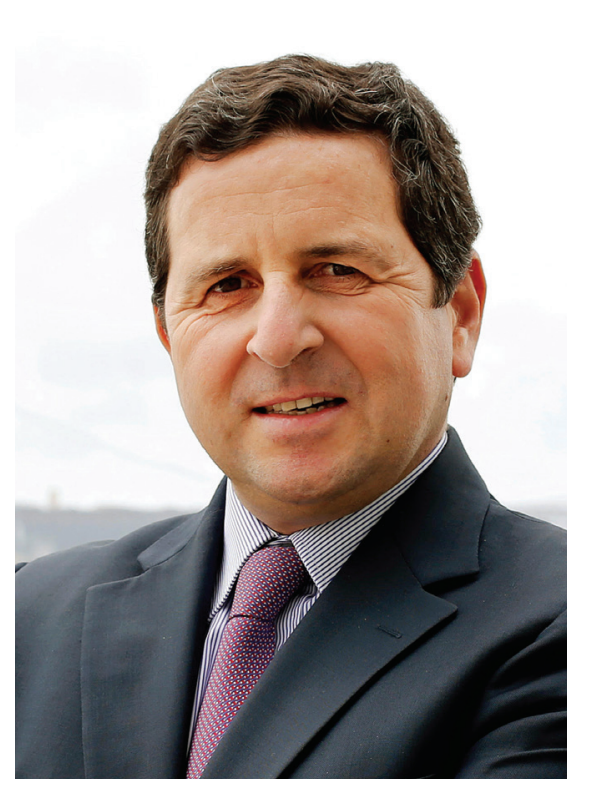

\title{
GAZETA MÉDICA INDEXADA NO DOAJ
}

\section{Gazeta Médica Indexed in the DOAJ}

\author{
Salvador de Mello
}

Um dos critérios determinantes na avaliação da qualidade de uma revista é a sua indexação em bases de dados internacionais.

Um dos recursos mais recomendados é o Directory of Open Access Journals (DOAJ), uma plataforma lançada em 2003 pela Universidade de Lund, na Suécia, que reconhece e agrega publicações de todo o mundo de elevada qualidade científica, de acesso livre e "peer-reviewed".

Encaro, por isso, com orgulho a recente indexação da Gazeta Médica no DOAJ, um reconhecimento que volta a posicionar a publicação científica da José de Mello Saúde entre as publicações de referência a nível internacional, à imagem do que aconteceu aquando do seu lançamento. A indexação da revista em bases de dados internacionais, como o Directory of Open Access Journals, reflete a qualidade desta produção.

Entre 1948 e 1964, ano em que foi descontinuada, a revista esteve indexada na maior base de dados bibliográfica internacional na área da biomedicina, a Medline, e esta é uma herança que continua a nortear o trabalho de toda a equipa editorial.

Porque a publicação científica é um instrumento primordial no ensino, formação e atividade clínica, retomámos a publicação em 2016 com renovado entusiasmo. Dois anos depois, estamos a colher os primeiros frutos deste compromisso que não se esgota nos nossos profissionais ou nas nossas unidades de saúde. A Gazeta Médica está aberta a toda a comunidade científica e obedece aos mais rigorosos critérios de edição, tornando-se um meio preferencial para divulgação de conhecimento científico.

É com esta garantia que convidamos à submissão de trabalhos científicos de qualidade à Gazeta Médica, publicada trimestralmente, e agora com o selo de qualidade DOAJ. Na atualidade, a avaliação da produtividade científica dos autores é cada vez mais apoiada nas bases de dados onde estão indexadas as revistas em que os seus artigos são publicados.

O nosso próximo objetivo é retomar a indexação na Medline, mas para tal, a Gazeta Médica tem de continuar a trabalhar na publicação de artigos de elevada qualidade, ampliando a diversidade nacional e internacional e aumentando a acessibilidade aos artigos que publica. Conseguir esta nova indexação é uma missão de todos - editores, revisores e autores - que exige esforço, tenacidade e capacidade de crítica. Uma missão possível com o compromisso de todos.

Salvador de Mello Presidente do Conselho de Administração da José de Mello Saúde 